\title{
Oceanobacillus caeni sp. nov., isolated from a Bacillus-dominated wastewater treatment system in Korea
}

Correspondence

Dong-Hun Lee

donghun@chungbuk.ac.kr

\author{
Ji-Hyun Nam, ${ }^{1}$ Wookeun $\mathrm{Bae}^{2}$ and Dong-Hun Lee ${ }^{1}$
}

\author{
${ }^{1}$ Department of Microbiology, Chungbuk National University, 12, Gaeshin-dong, Heungduk-gu, \\ Cheongju 361-763, Republic of Korea \\ ${ }^{2}$ Department of Civil and Environmental System Engineering, Hanyang University, 1271, Sa-1 dong, \\ Sangnok-gu, Ansan 425-791, Republic of Korea
}

\begin{abstract}
A Gram-positive, rod-shaped, spore-forming bacterium, strain $\mathrm{S}-11^{\top}$, was isolated from the activated sludge of a Bacillus-dominated wastewater treatment system in South Korea and was characterized using a polyphasic approach in order to determine its taxonomic position. Cells $(0.5-0.6 \times 2.0-2.2 \mu \mathrm{m})$ were motile by means of a single subpolar flagellum. They bore ellipsoidal endospores that lay in a central position in swollen sporangia. Phylogenetic analysis based on 16S rRNA gene sequences revealed that strain $\mathrm{S}-11^{\top}$ was a member of the genus Oceanobacillus. 16S rRNA gene sequence similarity values and DNA-DNA relatedness of strain $\mathrm{S}-11^{\top}$ to the type strains of other Oceanobacillus species were less than 96.2 and $66.0 \%$, respectively. Strain $\mathrm{S}-11^{\top}$ showed distinct differences in the $\mathrm{G}+\mathrm{C}$ content of the genomic DNA (33.6 mol\%). The major cellular fatty acids were iso- $\mathrm{C}_{14: 0}$, iso- $\mathrm{C}_{15: 0}$, anteiso- $\mathrm{C}_{15: 0}$ and iso$\mathrm{C}_{16: 0}$. The major isoprenoid quinone was MK-7. There were also some physiological differences in comparison with the type strains of Oceanobacillus species: tests for production of acetoin and acid production from dulcitol, erythritol, myo-inositol and sorbitol were positive. The results of DNA-DNA hybridization and physiological and biochemical tests allowed genotypic and phenotypic differentiation of strain $\mathrm{S}-11^{\top}$ from the six Oceanobacillus species and subspecies with validly published names. Strain $S-11^{\top}$ therefore represents a novel species, for which the name Oceanobacillus caeni sp. nov. is proposed, with the type strain S-11 ${ }^{\top}\left(=\right.$ KCTC $13061^{\top}$ $=$ CCUG $53534^{\top}=$ CIP $109363^{\top}$ ).
\end{abstract}

In Korea, the B3 (Bio Best Bacillus) process (Korean patent no. 151928) is an advanced wastewater treatment system in which Bacillus strains predominate. It has been reported that the process is able to remove nitrogen and phosphorus as well as organic matter efficiently (Choi et al., 2002). During a course of study on culture-independent bacterial community analysis in activated sludge of the B3 system, a large number of novel Bacillus-group strains was detected (data not shown). One of these isolates ( strain S-11 ${ }^{\mathrm{T}}$ ) was a member of the genus Oceanobacillus within the Bacillaceae and was the subject of a taxonomic investigation.

Bacteria belonging to the genus Oceanobacillus are aerobic, rod-shaped, spore-forming and moderately halophilic, and strains have been isolated from various environments. They

The GenBank/EMBL/DDBJ accession number for the $16 \mathrm{~S}$ rRNA gene sequence of strain $S-11^{\top}$ is $A B 275883$.

$16 S$ rRNA gene sequence-based maximum-parsimony and maximumlikelihood trees and detailed fatty acid profiles of strain $\mathrm{S}-11^{\top}$ and related strains are available as supplementary material with the online version of this paper. were originally assigned to the genus Bacillus, but reclassified within a new genus Oceanobacillus based on $16 \mathrm{~S}$ rRNA gene sequence comparisons and chemotaxonomic characteristics ( $\mathrm{Lu}$ et al., 2001). The genus Oceanobacillus currently comprises six species and subspecies: Oceanobacillus iheyensis (Lu et al., 2001), O. oncorhynchi subsp. oncorhynchi (Yumoto et al., 2005), O. oncorhynchi subsp. incaldanensis (Romano et al., 2006), O. picturae (Heyrman et al., 2003; Lee et al., 2006), O. chironomi (Raats \& Halpern, 2007) and O. profundus (Kim et al., 2007).

In the present study, we conducted phylogenetic (16S rRNA gene sequences), phenotypic, genotypic and chemotaxonomic analyses to determine the precise taxonomic position of strain $\mathrm{S}-11^{\mathrm{T}}$. On the basis of the results obtained in this study, we propose that strain $\mathrm{S}-11^{\mathrm{T}}$ should be placed in the genus Oceanobacillus as the type strain of a novel species.

A sludge sample was collected from the B3 wastewater treatment system in Ulsan, Korea. The sample was diluted 
with sterilized deionized water, incubated at $80{ }^{\circ} \mathrm{C}$ for $30 \mathrm{~min}$, spread onto a plate containing nutrient agar (Difco) and then incubated at $30{ }^{\circ} \mathrm{C}$ for 2 days. The isolate was routinely cultured on marine agar (Difco) and maintained as a glycerol suspension $(20 \% \mathrm{v} / \mathrm{v})$ at $-80{ }^{\circ} \mathrm{C}$.

Morphological characteristics were examined using phasecontrast (Nikon) and scanning electron (Philips) microscopy with cells grown at $30{ }^{\circ} \mathrm{C}$ for 2 days. Cells of strain S$11^{\mathrm{T}}$ were Gram-positive rods, $0.5-0.6 \times 2.0-2.2 \mu \mathrm{m}$ (Fig. 1a). The cells had ellipsoidal endospores which were produced centrally, causing swelling of the sporangia (Fig. 1b). The flagellum type was determined using transmission electron microscopy (Philips) with cells from the exponential phase of growth, in which cells were negatively stained with $1 \%(\mathrm{w} / \mathrm{v})$ phosphotungstic acid. Cells were motile by means of a single subpolar flagellum (Fig. 1c). Strain S- $11^{\mathrm{T}}$ could be clearly differentiated from previously described species of the genus Oceanobacillus by the central position of the endospores and the presence of a single subpolar flagellum.

Catalase and oxidase activities were determined using $3 \%$ $(\mathrm{v} / \mathrm{v})$ hydrogen peroxide and bioMérieux oxidase reagent, respectively. Other biochemical tests were performed using API 20E, API $50 \mathrm{CHB}$ and API ZYM kits (bioMérieux) with six type strains of the genus Oceanobacillus ( $O$. profundus CL-MP28 ${ }^{\mathrm{T}}$, O. picturae KCTC $3821^{\mathrm{T}}$, O. iheyensis DSM $14371^{\mathrm{T}}$, O. oncorhynchi subsp. oncorhynchi KCTC $3988^{\mathrm{T}}$, O. oncorhynchi subsp. incaldanensis DSM $16557^{\mathrm{T}}$ and O. chironomi DSM $18262^{\mathrm{T}}$ ) and strain S-11 ${ }^{\mathrm{T}}$. API strips were inoculated with a heavy bacterial suspension in API $50 \mathrm{CHB}$ medium or $0.85 \% \mathrm{NaCl}$ solution (bioMérieux) and incubated at the optimal temperature of each strain. The API tests were read after 24-48 h, depending on the growth rate of strains. $\mathrm{Na}^{+}$ requirement and tolerance of $0-20 \%(\mathrm{w} / \mathrm{v}) \mathrm{NaCl}$ were determined using nutrient agar (Difco), supplemented with appropriate amounts of $\mathrm{NaCl}$ in increments of $1 \%$. Growth was examined on marine agar (Difco) at $5-50{ }^{\circ} \mathrm{C}$ in increments of $5{ }^{\circ} \mathrm{C}$. Growth in the range of $\mathrm{pH}$ 6.0-11.0 was tested using marine broth (Difco). The $\mathrm{pH}$ of the medium was adjusted with $100 \mathrm{mM} \mathrm{Na} 2 \mathrm{HPO}_{4} / \mathrm{NaH}_{2} \mathrm{PO}_{4}$ buffer ( $\mathrm{pH}$ 6.0, 7.0 and 8.0) or $100 \mathrm{mM} \mathrm{NaHCO} / \mathrm{Na}_{2} \mathrm{CO}_{3}$ buffer ( $\mathrm{pH} 9.0,10.0$ and 11.0). Growth under anaerobic conditions was determined after 3 days incubation using oxidative/fermentative glucose media (Smibert \& Krieg, 1994) and marine agar (Difco) supplemented with $0.1 \%$ $\mathrm{KNO}_{3}$, which were prepared anaerobically in an Anaerocult system (Merck). The results of biochemical and physiological tests are given in Table 1 . Strain $\mathrm{S}-11^{\mathrm{T}}$ was distinct from known species of the genus Oceanobacillus in the production of acetoin and acid production from dulcitol, erythritol, myo-inositol and sorbitol. Hydrolysis of aesculin and gelatin was absent, whereas it was observed for the other type strains of the genus.

Isoprenoid quinones were isolated according to Minnikin et al. (1984) and analysed by HPLC as described by Collins
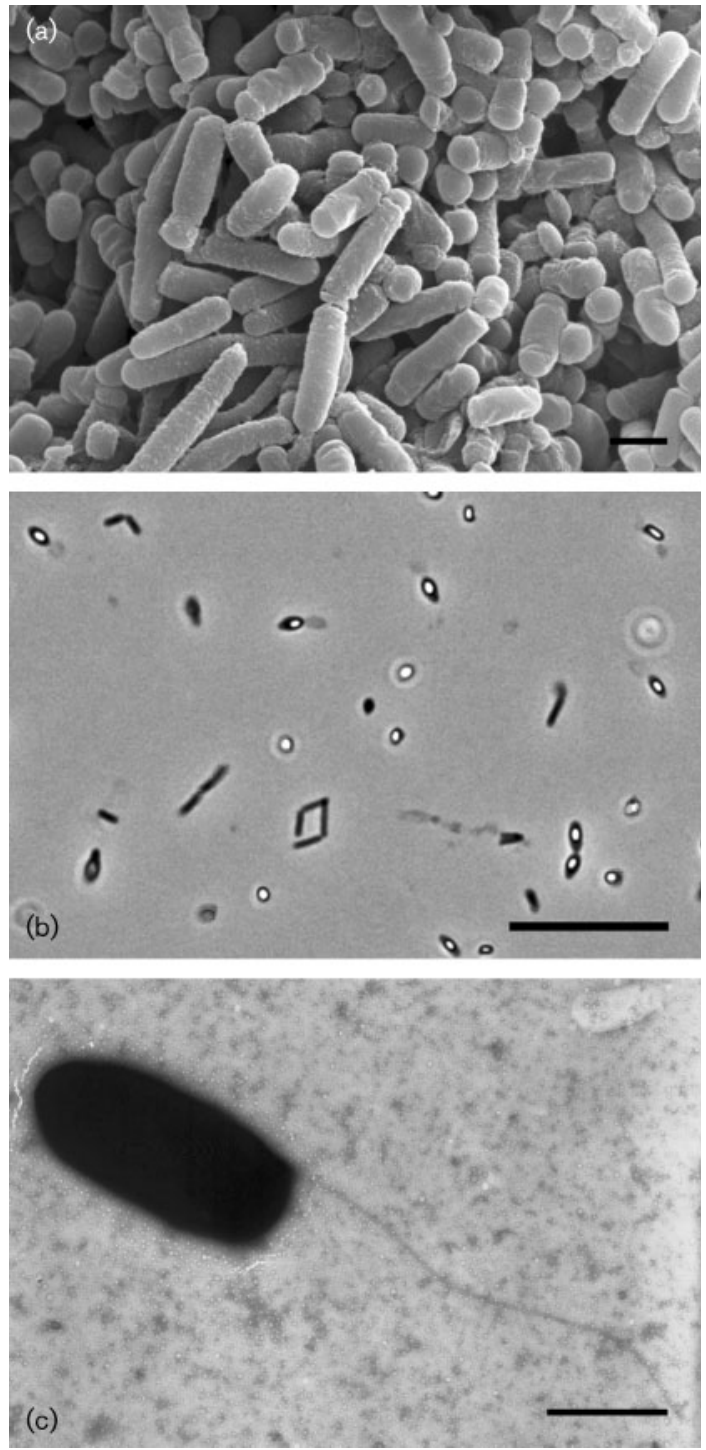

Fig. 1. (a) Scanning electron micrograph of cells of strain $S-11^{\top}$; cells are $0.5-0.6 \times 2.0-2.2 \mu \mathrm{m}$. (b) Photomicrograph of sporangia and vegetative cells of strain $\mathrm{S}-11^{\top}$. Ellipsoidal spores are formed in a central position in swollen sporangia. (c) Transmission electron micrograph of cells of strain $\mathrm{S}-11^{\top}$. For negative staining, one drop of culture was placed on a copper grid coated with $1 \%$ potassium phosphotungstic acid adjusted to $\mathrm{pH} 6.5$ with potassium hydroxide. Bars, $1 \mu \mathrm{m}(\mathrm{a}, \mathrm{c})$ and $10 \mu \mathrm{m}(\mathrm{b})$.

(1985). The major isoprenoid quinone in strain $\mathrm{S}-11^{\mathrm{T}}$ was MK-7. Cellular fatty acids of strain $S-11^{\mathrm{T}}$ were analysed as methyl esters by GLC using the Microbial Identification System (MIDI) at MicroID (Daejeon, Korea). Fatty acid methyl esters were prepared from biomass grown on marine agar at $30{ }^{\circ} \mathrm{C}$ for 2 days. Strain $\mathrm{S}-11^{\mathrm{T}}$ had anteiso$\mathrm{C}_{15: 0}(21.8 \%)$ as one of the major cellular fatty acids, as is the case for other species belonging to the genus Oceanobacillus. Clear differences were observed in the amounts of iso- $\mathrm{C}_{14: 0}$ (11.0\%), iso- $\mathrm{C}_{15: 0}$ (24.1\%), 
Table 1. Characteristics that differentiate strain $\mathrm{S}-11^{\top}$ from related Oceanobacillus species

Strains/species: 1, strain S-11 ${ }^{\mathrm{T}}$ (data from this study); 2, O. profundus (unless indicated, data from Kim et al., 2007); 3, O. picturae (Heyrman et al., 2003; Lee et al., 2006); 4, O. iheyensis (Lu et al., 2001); 5, O. oncorhynchi subsp. oncorhynchi (Yumoto et al., 2005); 6, O. oncorhynchi subsp. incaldanensis (Romano et al., 2006); 7, O. chironomi (Raats \& Halpern, 2007). Colony pigmentation and chains of cells were not observed in any strain. +, Positive; -, negative; w, weakly positive; ND, no data available.

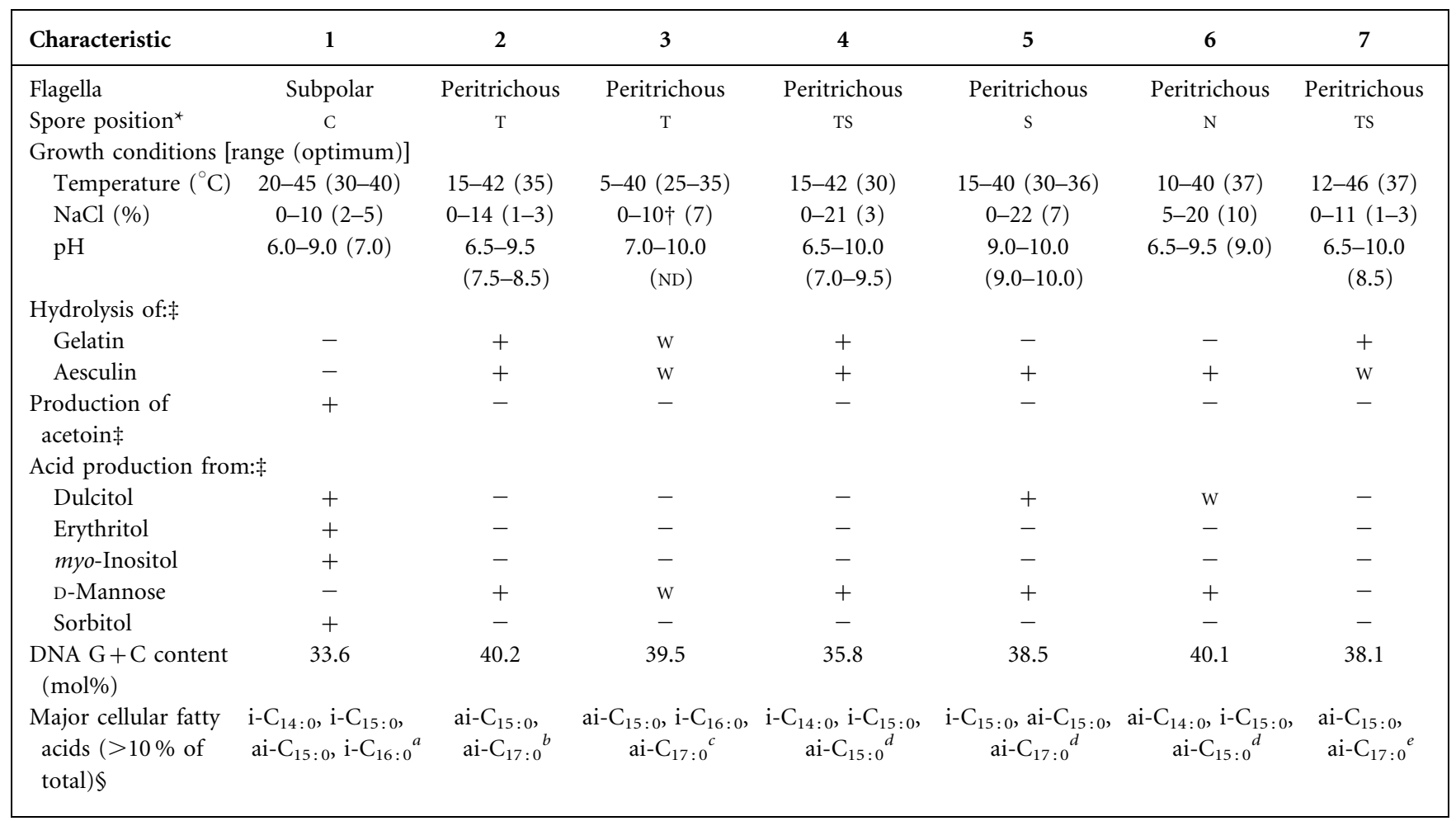

${ }^{*} \mathrm{C}$, Central; N, not sporulated; s, subterminal; T, terminal. Spore shape is ellipsoidal in all taxa with the exception of O. picturae, which has ellipsoidal or spherical endospores.

$\dagger$ Data from Raats \& Halpern (2007).

\$Determined for the type strain in this study using API 20E and API 50 CHB tests.

$\S$ Growth condition for fatty acid analysis: $a$, marine agar, $30{ }^{\circ} \mathrm{C}$; $b$, PYA medium, $27^{\circ} \mathrm{C}$; $c$, marine agar, $28^{\circ} \mathrm{C} ; d$, conditions not specified; $e$, tryptic soy agar, $28^{\circ} \mathrm{C}$. ai, Anteiso; i, iso.

iso- $\mathrm{C}_{16: 0}(17.0 \%)$ and iso- $\mathrm{C}_{17: 0}(8.8 \%)$ (see Supplementary Table S1 available in IJSEM Online).

The DNA G + C content was determined by HPLC analysis of deoxyribonucleosides using a reversed-phase column (Supelco) as described by Mesbah et al. (1989). The DNA $\mathrm{G}+\mathrm{C}$ content of strain $\mathrm{S}-11^{\mathrm{T}}$ was $33.6 \mathrm{~mol} \%$, which was lower than those of other species in the genus Oceanobacillus. In addition, a number of physiological and chemotaxonomic characteristics clearly distinguished our isolate from other phylogenetically related species (Table 1).

DNA was extracted and purified using a Wizard genomic DNA purification kit (Promega). The 16S rRNA gene was amplified with universal primers 27F and 1492R (positions based on the 16S rRNA gene of Escherichia coli; Lane, 1991). The amplified PCR product was purified with a Solgent PCR purification kit (Solgent) and sequenced directly by the fluorescent dye terminator method using an ABI 3730XL capillary DNA sequencer (Applied Biosystems) at Solgent (Daejeon, Korea). In order to obtain the nucleotide sequences of the $5^{\prime}$ and $3^{\prime}$ ends, the PCR product was cloned into the pGEM-T vector (Promega) and sequenced with the T7 and SP6 primers. A nearly complete $16 \mathrm{~S}$ rRNA gene sequence (1529 bp) was obtained. Strain $\mathrm{S}-11^{\mathrm{T}}$ showed the highest level of $16 \mathrm{~S}$ rRNA gene sequence similarity to O. profundus CL-MP2 $28^{\mathrm{T}}$ (96.2\%), followed by O. picturae LMG $19492^{\mathrm{T}}$ (95.1\%), the type strains of the two subspecies of $O$. oncorhynchi (94.6-94.8\%), O. iheyensis $\mathrm{HTE}_{381^{\mathrm{T}}}(94.3 \%)$ and $O$.

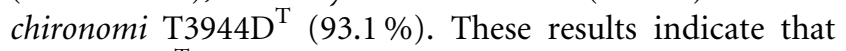
strain $\mathrm{S}-11^{\mathrm{T}}$ represents a novel species of the genus Oceanobacillus (Stackebrandt \& Goebel, 1994; RossellóMora \& Amann, 2001). The 16S rRNA gene sequence of strain S-11 $1^{\mathrm{T}}$ was aligned with those of representatives from the genus Oceanobacillus and related taxa using CLUSTAL_X 
software (version 1.83; Thompson et al., 1997). Phylogenetic trees were inferred from the regions available for all sequences (positions 98-1443 according to Escherichia coli numbering) using the neighbour-joining, maximum-parsimony and maximum-likelihood methods within the PHYLIP package (Felsenstein, 1989). The evolutionarydistance matrix for the neighbour-joining method was generated according to Jukes \& Cantor (1969). The topology of phylogenetic trees was evaluated by bootstrap resampling based on 1000 replicates (Felsenstein, 1985). The neighbourjoining tree shown in Fig. 2 indicates that strain $\mathrm{S}-11^{\mathrm{T}}$ belongs to the genus Oceanobacillus, but forms a separate clade within this genus. The other phylogenetic methods recovered the same tree topology of the genus Oceanobacillus (see Supplementary Figs S1 and S2).

DNA-DNA hybridization was used to determine genomic DNA relatedness. Levels of DNA relatedness were determined by the initial renaturation rate method (De Ley et al., 1970). We chose three reference strains, O. profundus CL-MP $28^{\mathrm{T}}$, O. picturae LMG $19492^{\mathrm{T}}$ and O. iheyensis HTE $381^{\mathrm{T}}$, for the DNA-DNA hybridization experiments. DNA-DNA reassociation values between strain $\mathrm{S}-11^{\mathrm{T}}$ and the three reference strains were less than $44.8,60.1$ and $66.0 \%$, respectively.

We have isolated a strain belonging to a novel Oceanobacillus species, strain S- $11^{\mathrm{T}}$, from activated sludge of a wastewater treatment system in which Gram-positive bacteria belonging to Bacillus are predominant. 16S rRNA gene sequence comparison and DNA-DNA hybridization results showed that strain $\mathrm{S}-11^{\mathrm{T}}$ was most closely related to the genus Oceanobacillus. However, it could be differentiated clearly from the other species in this genus by its morphological and physiological characteristics. There were distinct morphological differences between strain S$11^{\mathrm{T}}$ and the type strains of Oceanobacillus species; strain S$11^{\mathrm{T}}$ had a single subpolar flagellum and spores were formed in a central position. Moreover, other physiological differences were found such as the inability to hydrolyse aesculin and gelatin and the ability to produce acetoin and to produce acid from dulcitol, erythritol, myo-inositol and sorbitol. Strain S-11 ${ }^{\mathrm{T}}$ showed distinct differences in DNA $\mathrm{G}+\mathrm{C}$ content and in the proportions of some fatty acids, particularly iso- $\mathrm{C}_{14: 0}$ and iso- $\mathrm{C}_{16: 0}$, from other Oceanobacillus species. The 16S rRNA gene sequence similarity and DNA-DNA relatedness of strain S- $11^{\mathrm{T}}$ with respect to the type strains of other Oceanobacillus species were less than 96.2 and $66.0 \%$, respectively.

On the basis of the genotypic and phenotypic data presented in this paper, strain S- $11^{\mathrm{T}}$ should be designated the type strain of a novel species within the genus Oceanobacillus, for which the name Oceanobacillus caeni sp. nov. is proposed.

\section{Description of Oceanobacillus caeni sp. nov.}

Oceanobacillus caeni (cae'ni. L. gen. n. caeni of mud).

Cells are Gram-positive, aerobic rods $(0.5-0.6 \times 2.0-$ $2.2 \mu \mathrm{m}$ ), motile by means of a single subpolar flagellum. Cells produce ellipsoidal spores in a central position. Colonies grown on marine agar are circular, low-convex, smooth, semi-translucent and cream-coloured. Growth occurs at $20-45{ }^{\circ} \mathrm{C}$, with optimum growth at $30-40{ }^{\circ} \mathrm{C}$. The $\mathrm{pH}$ range for growth is 6.0-9.0 (optimal at $\mathrm{pH}$ 7.0). No growth occurs with $\mathrm{NaCl}$ concentrations of more than $10 \%$, while optimal growth occurs with $\mathrm{NaCl}$ concentrations of $2-5 \%$. Catalase and oxidase activity tests are positive. Can not reduce nitrate or nitrite. Produces $\alpha$ glucosidase and acetoin, but not aesculin dihydrolase, arginine dihydrolase, $\beta$-galactosidase, lysine decarboxylase, ornithine decarboxylase, urease, $\mathrm{H}_{2} \mathrm{~S}$, tryptophan deaminase, gelatinase or indole. Acid is produced from glycerol, L-arabinose, ribose, D-xylose, glucose, fructose, dulcitol, erythritol, myo-inositol, sorbitol, $\mathrm{N}$-acetylglucosamine and maltose. Acid production from mannitol and melibiose is weak. The DNA $\mathrm{G}+\mathrm{C}$ content of the type strain is $33.6 \mathrm{~mol} \%$. The major cellular fatty acids are iso- $\mathrm{C}_{15: 0}$ $(24.1 \%)$, anteiso- $\mathrm{C}_{15: 0}(21.8 \%)$, iso- $\mathrm{C}_{16: 0}(17.0 \%)$, iso$\mathrm{C}_{14: 0}(11.0 \%)$, iso- $\mathrm{C}_{17: 0}(8.8 \%)$, anteiso- $\mathrm{C}_{17: 0}(6.3 \%)$, $\mathrm{C}_{16: 1} \omega 7 c$ alcohol (4.1\%), $\mathrm{C}_{16: 0}(2.3 \%)$ and $\mathrm{C}_{18: 0}(2.0 \%)$. The major isoprenoid quinone is MK-7.

The type strain, S- $11^{\mathrm{T}}\left(=\right.$ KCTC $13061^{\mathrm{T}}=$ CCUG $53534^{\mathrm{T}}$ $=$ CIP $109363^{\mathrm{T}}$ ), was isolated from activated sludge of a Bacillus-dominated wastewater treatment system in South Korea.
Fig. 2. Neighbour-joining phylogenetic tree based on 16S rRNA gene sequences of strain $\mathrm{S}-11^{\top}$, type strains of other Oceanobacillus species and related taxa. Numbers on branches indicate bootstrap values derived from 1000 samples. Bootstrap probability values less than $50 \%$ were omitted. Bar, $0.01 K_{\text {nuc. }}$. 


\section{Acknowledgements}

The authors thank Ms Moon Eun Young and Dr Jongsik Chun for technical assistance. Thanks are also due to Professor Byung Cheol Cho (Seoul National University) for the gift of the type strain of Oceanobacillus profundus. This research was supported by a grant (code no. I ${ }^{2}$ WATERTECH 04-7) from $\mathrm{I}^{2}$ WaterTech of Eco-STAR project funded by Ministry of Environment, Korea.

\section{References}

Choi, Y. S., Hong, S. W., Kim, S. J. \& Chung, I. H. (2002). Development of a biological process for livestock wastewater treatment using a technique for predominant outgrowth of Bacillus species. Water Sci Technol 45 (12), 71-78.

Collins, M. D. (1985). Analysis of isoprenoid quinones. Methods Microbiol 18, 329-366.

De Ley, J., Cattoir, H. \& Reynaerts, A. (1970). The quantitative measurement of DNA hybridization from renaturation rates. Eur $J$ Biochem 12, 133-142.

Felsenstein, J. (1985). Confidence limits on phylogenies: an approach using the bootstrap. Evolution 39, 783-791.

Felsenstein, J. (1989). PHYLIP - phylogeny inference package (version 3.2). Cladistics 5, 164-166.

Heyrman, J., Logan, N. A., Busse, H.-J., Balcaen, A., Lebbe, L., Rodriguez-Diaz, M., Swings, J. \& De Vos, P. (2003). Virgibacillus carmonensis sp. nov., Virgibacillus necropolis sp. nov. and Virgibacillus picturae sp. nov., three novel species isolated from deteriorated mural paintings, transfer of the species of the genus Salibacillus to Virgibacillus, as Virgibacillus marismortui comb. nov. and Virgibacillus salexigens comb. nov., and emended description of the genus Virgibacillus. Int $J$ Syst Evol Microbiol 53, 501-511.

Jukes, T. H. \& Cantor, C. R. (1969). Evolution of protein molecules. In Mammalian Protein Metabolism, vol. 3, pp. 21-132. Edited by H. N. Munro. New York: Academic Press.

Kim, Y.-G., Choi, D. H., Hyun, S. \& Cho, B. C. (2007). Oceanobacillus profundus sp. nov., isolated from a deep-sea sediment core. Int J Syst Evol Microbiol 57, 409-413.

Lane, D. J. (1991). 16S/23S rRNA sequencing. In Nucleic Acid Techniques in Bacterial Systematics, pp. 115-175. Edited by E. Stackebrandt \& M. Goodfellow. Chichester: Wiley.

Lee, J.-S., Lim, J.-M., Lee, K. C., Lee, J.-C., Park, Y.-H. \& Kim, C.-J. (2006). Virgibacillus koreensis sp. nov., a novel bacterium from a salt field, and transfer of Virgibacillus picturae to the genus Oceanobacillus as Oceanobacillus picturae comb. nov. with emended descriptions. Int J Syst Evol Microbiol 56, 251-257.

Lu, J., Nogi, Y. \& Takami, H. (2001). Oceanobacillus iheyensis gen. nov., sp. nov., a deep-sea extremely halotolerant and alkaliphilic species isolated from a depth of $1050 \mathrm{~m}$ on the Iheya Ridge. FEMS Microbiol Lett 205, 291-297.

Mesbah, M., Premachandran, U. \& Whitman, W. B. (1989). Precise measurement of the $\mathrm{G}+\mathrm{C}$ content of deoxyribonucleic acid by high-performance liquid chromatography. Int J Syst Bacteriol 39, 159-167.

Minnikin, D. E., O’Donnell, A. G., Goodfellow, M., Alderson, G., Athalye, M., Schaal, K. \& Parlett, J. H. (1984). An integrated procedure for the extraction of bacterial isoprenoid quinones and polar lipids. J Microbiol Methods 2, 233-241.

Raats, D. \& Halpern, M. (2007). Oceanobacillus chironomi sp. nov., a halotolerant and facultatively alkaliphilic species isolated from a chironomid egg mass. Int J Syst Evol Microbiol 57, 255-259.

Romano, I., Lama, L., Nicolaus, B. \& Poli, A. (2006). Oceanobacillus oncorhynchi subsp. incaldanensis subsp. nov., an alkalitolerant halophile isolated from an algal mat collected from a sulfurous spring in Campania (Italy), and emended description of Oceanobacillus oncorhynchi. Int J Syst Evol Microbiol 56, 805-810.

Rosselló-Mora, R. \& Amann, R. (2001). The species concept for prokaryotes. FEMS Microbiol Rev 25, 39-67.

Smibert, R. M. \& Krieg, N. R. (1994). Phenotypic characterization. In Methods for General and Molecular Bacteriology, pp. 607-654. Edited by P. Gerhardt, R. G. E. Murray, W. A. Wood \& N. R. Krieg. Washington, DC: American Society for Microbiology.

Stackebrandt, E. \& Goebel, B. M. (1994). Taxonomic note: a place for DNA-DNA reassociation and $16 \mathrm{~S}$ rRNA sequence analysis in the present species definition in bacteriology. Int J Syst Bacteriol 44, 846-849.

Thompson, J. D., Gilson, T. J., Plewniak, F., Jeanmougin, F. \& Higgins, D. G. (1997). The CLUSTAL_X windows interface: flexible strategies for multiple sequence alignment aided by quality analysis tools. Nucleic Acids Res 25, 4876-4882.

Yumoto, I., Hirota, K., Nodasaka, Y. \& Nakajima, K. (2005). Oceanobacillus oncorhynchi sp. nov., a halotolerant obligate alkaliphile isolated from the skin of a rainbow trout (Oncorhynchus mykiss), and emended description of the genus Oceanobacillus. Int J Syst Evol Microbiol 55, 1521-1524. 